Article

HONORATA JAKUBOWSKA *

Adam Mickiewicz University in Poznań, Poland

\title{
NO MORE GRID GIRLS AT FORMULA ONE: THE DISCOURSE ANALYSIS ON HOSTESSES' SEXUALIZED BODIES, OBJECTIFICA- TION, AND FEMALE AGENCY
}

\begin{abstract}
At the beginning of 2018, Liberty Media, the owner of Formula One (hereafter, F1), decided to drop so-called grid girls from the race weekends beginning with the 2018 season, which has created an opportunity to analyze the perception of hostesses' status and their bodies in contemporary sport. The discourse on the decision and the partial concessions in its enforcement is analyzed within the theoretical framework related to second and third waves of the feminist movement and the concepts of sexual objectification and agency. The results reveal that the grid girls' presence is perceived both as unsuitable for modern times, values and \#metoo culture climate and as "normal" and a "good tradition." Additionally, the grid girls themselves accuse feminists of having caused them to lose their jobs, arguing that, although their positions are based on physical attractiveness and a sexualized body, it has been done by them voluntarily and with pleasure. The discourse on gird girls in F1 fits into the critical discourses on female (sexualized) body images in sport, but, on the other hand, it includes persons who have usually not been taken into account because of their auxiliary role in sports events.
\end{abstract}

Keywords: sport, female body, objectification, agency, hostesses, Formula One.

\# Corresponding author: Adam Mickiewicz University in Poznań, Szamarzewskiego 89 C, 60-568 Poznań, Poland. E-mail: honorata@amu.edu.pl 


\section{Introduction}

In January 2018, Liberty Media, the owner of F1, decided to drop so-called gridgirls from the race weekends beginning with the 2018 season. The decision has concerned not only F1 but also F2 and GP3 races. The statement made by Sean Bratches, Managing Director of Commercial Operations at Formula 1, reads:

Over the last year, we have looked at a number of areas which we felt needed updating so as to be more in tune with our vision for this great sport.

While the practice of employing grid girls has been a staple of Formula 1 Grands Prix for decades, we feel this custom does not resonate with our brand values and clearly is at odds with modern-day societal norms. We don't believe the practice is appropriate or relevant to Formula 1 and its fans, old and new, across the world ("Formuła 1 już bez grid girls", 2018)

Grid-girls' duties included holding umbrellas or driver name-boards on the grid, indicating the corridor to the podium during a decoration ceremony. In the frame of their promotional tasks, they were usually wearing clothing with the name of a sponsor. The owner of F1 has decided that the grid-girls will be replaced by grid-kids, i.e. children selected from the junior drivers taking part, e.g. in go-kart competitions. As Jean Todt, the president of the Fédération Internationale de l'Automobile (FIA), said:

Formula 1 is the top of motorsport and the dream of every young driver who takes part in the junior series. We are happy that we can bring this dream closer to the children, giving them the chance to stand next to their idols ("Formuła 1. Grid kids zastąpią grid girls. Środowisko protestuje”, 2018)

This decision has met with different reactions and has been widely commented on by different figures in the motorworld: sponsors, drivers, fans, sports journalists, and the hostesses themselves. At the same time, it has raised the issue of the hostesses' status in other sports disciplines. The arguments used referred to a number of contexts, including tradition, perception of sport as both business and entertainment, women's sexual objectification, women's sexual harassment, right to work, etc. The resistance to the F1 environment has led the F1 authorities to agree to the presence of the grid-girls during some events, e.g. the Grand Prix in Monaco and, probably, in Sochi.

The discourse on the decision and the partial concessions in its enforcement have created an opportunity to analyze the perception of hostesses' status in contemporary sport. In these times of a rising awareness of women's rights and empowerment, as well as of resistance towards any form of sexual harassment, 
as evidenced by the social action \#metoo, the decorative role of grid girls (and, more generally, hostesses) and their scanty, sexy clothing, have started to be questioned. However, as the discourse reveals, their presence during the sports events has a lot of supporters. The aim of this paper is to analyze this based on heteronormativity discourse and to indicate and discuss the main themes and arguments that have been used by the main actors. As such, it provides new knowledge on women's status in the sport by its focus on this category of sports events' participants that have been, unlike the athletes, almost omitted in the social research. One can read several publications on cheerleaders (see e.g. Adams and Bettis 2003; Bettis and Adams 2006; Morritz 2011; Organista and Mazur 2016); however, in their case, they can be and are perceived as athletes, although during the matches they play also a decorative role. In the case of grid girls (hostesses), one can speak only about this role.

The paper is organized as follows. At the beginning, it provides information on hostesses in different sports disciplines to introduce the analyzed issue. Then, the theoretical framework focused on women's sexualization, objectification, and agency is presented. Next, the study of methodology is shortly described. The findings' part starts with the presentation of the discourse's main actors and is followed by the analysis of the main themes. The paper ends with concluding thoughts.

\section{Hostesses in the sports disciplines}

The history of grid girls began in the 1960s in Japan. Rosa Ogawa, Japanese model and singer, has been recognized as the first girl "race queen" during the motorsports event, advertising an oil company (Saner, 2018). In the next two decades, promotional models have appeared in the other countries, including the United States, United Kingdom, and tight-fitting outfits have become their unofficial uniform (Brennan, 2018). The use of grid girls became popularized in the 1990s, due to Eddie Jordan, the owner of the Jordan Grand Prix team. At that time, apart from a glamorous role, their promotional role has increased. As noted in the Introduction, during the races, grid girls hold up the grid number, as well as welcome and cheer the best three racers on the podium. However, they are not only perceived by their duties during a particular Grand Prix but, also, in a wider context, as the ambassadors of $\mathrm{F} 1$ and the hosting cities and countries.

By its decision, the owner of $\mathrm{F} 1$ has joined other motorsports, which have also stopped using the hostesses during the races. As an example, one can indicate the World Endurance Championship, which runs the Le Mans sportscar race. The same changes could be observed in a totally different sport, i.e. darts, where the walk-on girls have been used since the 1980s. The decision of the Professional Darts Corporation to end this practice was taken only a few days before the announcement of F1's owner.

However, there are still several sports in which the hostesses are present. The first of these is boxing, where, similar to car racing, these girls have appeared since the 60s. During an event, they walk around the ring between rounds and 
hold up numbered cards. Ring cards girls are also used in the mixed martial arts (MMA) during the galas organized by the main federations, such as Ultimate Fighting Championship (UFC) and Polish Konfrontacja Sztuk Walki (KSW). In Poland, the umbrella girls can also be seen during one of the most popular races, the speedway competitions. It is worth mentioning that some Polish sports websites, e.g. WP Sportowe Fakty (Wirtual Poland [WP] Sports Facts, www.sportowefakty.wp.pl), have photo galleries dedicated to speedway grid girls, hostesses and cheerleaders. It should be mentioned that the decision of F1's owner has also influenced the speedway world, but not in Poland. However, in spite of the fact that the vast majority of speedway world, including the main sponsor of Grand Prix - Monster Energy, is in favor of continuing the use of grid girls during speedway competitions; the organizer of Grand Prix in Sweden, for example, has decided to waive them from participation.

The hostesses, called podium girls, are also present during cycling events. They have been present in the most important tours: the Tour de France, Vuelta a España, and Giro d'Italia since the 1960s. Also, in one case in this sport, some criticized the kissing of the winner on the cheek one could observe some critics concerning kissing a winner on the cheek and the cyclists' behavior towards the girls ("Which sports still use...", 2018). It has been followed by a particular decision by the organizer of the World Championship in 2017 in Bergen, Norway, who decided to replace hostesses with young female and male cyclists wearing folk costumes. The practice to include children and youth has been also adapted, as mentioned above, in F1. There were also cases where, instead of women, male models appeared during the races. This practice can be observed in MMA - one of the most 'masculine' sports, with, however, a growing presence of female fighters. One of them, Mikaela Lauren, the world champion from Sweden, before her fight in Sweden in 2016, gave an ultimatum to fight's organizer concerning the presence of ring boys instead of ring girls. In Poland, ring boys were presented during the first Ladies Fight Night in December 2015. One can mention also Elias Theodorou, UFC fighter and model, who played the role of ring boy during women's fights in MMA in February 2018.

Thus, there are still several sports disciplines in which one can observe women in a decorative and promotional role. Although one can observe some changes, e.g. men in the role of ring boys, they should be perceived rather as the exceptions. Additionally, as has already been mentioned, even F1's owner, very soon after its decision to stop using grid-girls, has accepted their presence during some events. 


\section{The theoretical framework: between sexual objectification and agency}

The discourse on elimination of the grid girls can be considered within the theoretical framework related to the second and third waves of the feminist movement and the perception of sexualization within them (Heywood and Dworkin 2003). This approach has been discussed in the articles on cheerleaders (Morritz 2011; Organista and Mazur 2016), as well as the Lingerie Football League, rebranded as Legends Football League (Khomutova and Channon 2015). However, first, the male character of sport, including motorsports, should be emphasized.

There are a vast number of publications which have presented the male domination in the sports field, which is visible in its history, sports organizations, media, etc. Sport is perceived as one of the 'bastions of masculinity' (Messner 1992; Pronger 1990; McKay, Messner and Sabo 2000, Burstyn 2004) and a field where 'hegemonic masculinity' (Connell 1987; Connell, Messerschmidt 2005) is reproduced. This kind of masculinity is understood, firstly, as a certain pattern of masculinity, defined by opposition to what is 'feminine', i.e. women and homosexuals, and, secondly, as a set of practices which reproduces male domination. One of the main features that creates hegemonic masculinity is heterosexual orientation, which is reproduced by women's objectification and sexualization.

In the opinion of some authors (e.g. Anderson 2011; McCormack 2011), one can observe a new gender order in sport: "hierarchy without hegemony," and growing acceptance for other types of masculinity; however, it seems that some sports disciplines, e.g. motorsports, still remain male territory. The automobile, both in everyday life and professional sports, is perceived as a male world; as noted by Balkmar (2012), the relationship between men, masculinity and cars is perhaps one of the most taken-for-granted gendered relations one can think of. Cars and other motorized vehicles are closely tied to the construction and perception of masculinity (Mellström 2002, 2004; Uteng and Cresswell 2008; Letherby and Reynolds 2009). Women as drivers are barely present in professional motorsports, and they constitute also a significant minority among the fans. However, they have been always perceived as a decorative element of these male worlds. ${ }^{2}$

Taking into account the dominant discourse on women in sport, related to the second wave of feminism, the role of hostesses in sport is considered as one of the prime examples of women's sexualization and objectification. These issues have been discussed mainly in relation to female athletes' media coverage in which, unlike the male athletes, women are presented more often by way of their physical attractiveness than sports skills (Kim, Walkosz and Iveson 2006; Bissell and Duke 2007, Fink 2015). In the case of athletes, these images emphasized 'femininity', understood both as heterosexual orientation and female traits, such as fragility and passivity, distracting attention from their sports strength (Heywood and Dworkin, 2003). Additionally, this way to present their bodies,

\footnotetext{
${ }^{2}$ It is worth noticing that this practice can be also observed during motor fairs when presentation of new car models is
} made in the presence of hostesses, and, similar to the cars, they can also be admired during the fair and other motor shows. 
can be perceived as their commodification, a tool to attract the attention of male sports fans (Davis, 2010; McLeod, 2010; Khomutova and Channon 2015). In this context, female bodies, even if strong and athletic sportive, are considered mainly as 'body-for-others' (Bourdieu 2004:82), i.e. the bodies that are presented to be observed and admired by men.

However, the perception of women's sexualization in sport can be also read in another way. Their sexualized images can be perceived as a mean of female empowerment and female agency. In this context, a woman is not sexualized by others (men), but decides herself to emphasize her physical attractiveness and femininity (Heywood and Dworkin 2003; Heywood 2008). Khomutova and Channon (2015), in their study on the Legends Football League, noticed, giving the examples of roller derby or pole dancing studies, that "the role of women's agency in simultaneously embodying (hetero)sexy femininities and 'empowered' subjectivities" has been discussed in a number of papers on women in sport and leisure activities. This interpretation can be related to the third wave of feminism within which women are considered to a smaller extent as a collective, but more often as individuals and by individual decision. In this context, a woman decides the way she will present her body and her own sexuality. Moreover, the emphasis on sexuality can be considered in the frame of female empowerment, instead of objectification.

In the study conducted by the article's author, female athletes admitted that they knowingly take advantage of their femininity for marketing purposes and use different practices to present their bodies in a more feminine way. (Jakubowska 2014) In another study, female beach volleyball players emphasized that their scanty clothes are important to attract sponsors, media, and fans and these are treated by them as 'part of the game'. As a consequence, they do not protest against this type of sportswear; on the contrary, the players use their physical attractiveness to increase their popularity and gain profits (von der Lippe 2013). This issue has been also emphasized by Rowe (2004: 154), who noticed that athletes accept their sexualized images in media (which is also a concern more and more often for male athletes), increasing in this way their media status and earnings. Therefore, one can say that sexualization of the female body is a practice used not only by men towards women but also by women themselves. (Jakubowska 2014)

These two ways of perception of a sexualized female body can be crucial in discussing the role of hostesses in the sports events that the pre-analysis has revealed. As mentioned above, there are a number of publications that have analyzed this issue with reference to female athletes, but, contrary to this, this issue is almost ignored in the case of hostesses in the sport. Therefore, on the one hand, the discourse on gird girls in F1 fits into these critical discourses on female body images in sport, but, on the other hand, it includes those persons who have usually not been taken into account because of their auxiliary role in the sports events. 


\section{Methodology Data Collection}

The data informing the study were taken from a range of news outlets accessed via the Internet. All were written in Polish and ostensibly based in Poland (i.e. using the .pl domain); the sites were located through Google Poland searches of keywords: (1) grid girls, (2) grid girls F1, (3) grid girls Formuła 1 (Polish form of 'Formula 1'). The websites returning hits from these searches included various different media outlets, such as national newspapers', TV news channels', and radio stations' online services, racing websites, sports websites, as well as entertainment websites and forums. The author decided not to include the last two types of websites, taking into account their nature. After exclusion of re-posted items, previously sampled stories, and only visual items, 60 samples have been gathered. They were published between the $31^{\text {st }}$ of January, i.e. the date of Liberty Media's decision, and the $20^{\text {th }}$ of April 2018.

\section{Data analysis}

The analysis of online sources data was limited to the statements of the different social actors, e.g. the owner of F1, the drivers, and grid girls; internet commentaries and journalists' opinions were not taken into account. Giving voice to the participants (Fine, 2002), the author decided to use thematic analysis (Boyatzis 1998; Braun and Clarke, 2006) to identify the main themes that have appeared in their discourse. First, the initial codes were generated and, in the following phase, they were assigned to the themes that emerged during the initial coding process. Finally, the themes were reviewed and the extracts from the data were selected to illustrate them. The quotes were organized by their relevance to each theme and analyzed on the basis of several criteria, including frequency, specificity, emotion, and extensiveness (Krueger and Casey, 2000). Finally, the data were interpreted and the quotations were used to illustrate discussed issues.

\section{Findings}

\section{The main actors of the grid girls' media discourse}

The analysis revealed few main actors who have created media discourse on the grid girls in F1. First, was Liberty Media, the owner of Formula 1 since 2016 and its representatives. They not only launched the discourse by their decision and the announcement made by Sean Bratches, Managing Director, but also their words were recalled in a number of the articles that have been published in the following days. Second, a voice was given to the grid girls themselves in two ways: (1) their opinions taken, for example, from the interviews were cited by journalists and (2) their tweets were included in the articles. Third, the journalists presented the drivers' opinions using extracts from conferences, interviews, and printing their 
tweets. At the same time, opinions of other persons related to F1 racing, e.g. the team owner and Grand Prix (GP) organizers, have been recalled. The fourth actor, who had a specific status, was the feminist movement itself. Although, generally, a voice was not given to feminists, they appeared as one of the reasons that have led to the decision on grid girls. Additionally, "[t]he statement of the use of grid and ring girls in sport" of The Women's Sport Trust from December 2017, was recalled and/or partially quoted. And, finally, some journalists, mainly those related to sports websites, did not neglect to present their own viewpoints.

It should be noted, however, that readers had the opportunity to get familiar with just a limited number of opinions. For instance, in the case of grid girls, journalists usually quoted the same sentences and presented the same tweets from a few of them. Therefore, one did not have the possibility to learn about different and more heterogeneous reactions, and it is not possible to talk about a general acceptance or rejection of Liberty Medias decision. In spite of limited sources, the analysis of media discourse is significant in taking into account the meaning of media in contemporary sports and their meaning in sport's perception (Rowe 2004, Smart 2005, Fink 2015). Media create not only the image of sports itself and its character, e.g. male vs. female sport, elite vs. common, but also reproduce gender images and stereotypes, as well as the gendered order. From this perspective, media can both strengthen the existing gender dichotomies and question them, as well as create the perception of a female sexualized body and female agency.

In the analyzed discourse, one could find a few main themes around which the discourse was organized.

\section{Old practices vs. Modern-day societal norms}

The decision to stop using grid girls during race weekends has been presented in the frame of the dichotomy concerned with the social norms that were common in prior times as opposed to new, modern norms. This contradiction can be observed in the F1 owner's statement which references the need for updating some areas of the racing Grand Prix events, found in the sentence:

While the practice of employing grid girls has been a staple of Formula 1 Grands Prix for decades, we feel this custom does not resonate with our brand values and clearly is at odds with modern-day societal norms ("Formuła 1. "Grid kids" zastąpią "grid girls"”, 2018)

Similar statements were made by other representatives of F1. In December 2017, Ross Brawn, managing director of motorsports in Liberty Media, said:

There's a lot of people respect the tradition of the grid girls and there's people who feel that it has become a bit dated, so we're addressing that ("Grid girls znikną z torów Formuły 1", 2018) 
While in February 2018, Chast Carey, F1 chief executive, admitted that, although he personally preferred to keep grid girls during F1 events,

[w] hen you have as many people as I found who really felt it was outdated and who felt it didn't belong in the sport today, you have to be cognisant of that. The number that were passionately positive on the other side were much smaller (...) In today's world there are obviously different sensitivities to 10-12 years ago. I don't think you can just be stubborn (“Formuła 1 obiecuje ...”, 2018)

It should be noted, however, that he promises also that "pretty girls" will still be present during the races and the discipline will remain "glamorous", which will be discussed later.

Therefore, one on the hand, there has been a long tradition of grid girls during the races; on the other hand, the owners of F1 are convinced that the status of women has changed in the last decades. According to the analyzed discourse, the decision on scrapping the grid girls was taken to avoid the accusation of sexism, women's objectification and eroticization. Elimination of women, who only accessorise the events, has been perceived as consistent with 'modern' social norms. As such, the decision was applauded by the representatives of two other auto racing series, Formula E and WEC (World Endurance Championship), who eliminated themselves grid girls in 2016 (FE) and in 2015 (WEC):

Formula E with understanding approved F1 decision to stop using grid girls. Welcome to the 21 st century - commented the spokesperson for the Formula E series (Kuczera 2018a)

For me, it is the past. Today, a woman's status is different - said than [in 2015], Gerard Neveau, WEC general director (Kuczera 2018a)

The decision of Liberty Media has been also considered within the frame of political correctness, which could also be considered as a "modern" norm. However, in the quoted opinions, political correctness has been perceived in a negative way, as "exaggerated", "crazy" or "fanatical" and, as a consequence, harmful. This point of view has been presented mainly by the grid girls themselves:

It is disappointing that Formula 1 has followed the minority's vote to be politically correct. (Charlotte Gash, one of the grid girls for the BBC, quoted after: Prochota 2018)

Wake me up when all this crazy political correctness is over. I love to be a grid girl (Sophie Wright, quoted after: Prochota 2018) 
There was no single article which presented 'political correctness' as an important principle, worth following. In each case, it was viewed as a rule that imposes artificial norms and change, in a negative way, on some customs and traditions that have existed for many years.

\section{Grid girls against feminists}

In the analyzed discourse, one could find only the statements of grid girls that were not satisfied with the decision of F1's owner. Taking into account that they had lost their jobs and the possibility to earn money, what has been emphasized in their statements or tweets (using the \#SaveTheWalkOnGirls) is not surprising. The more interesting thing is that they have accused the feminists of causing this situation. This is all the more puzzling as the decision was taken by men who are key people in F1 and Liberty Media and are generally dominant in sports, mainly, the so-called male sports and organizations (Hovden 2000; Pfister and Radtke 2009; Claringbould and Knoppers 2012).

In the analyzed articles, only one feminist organization has appeared: Women's Sport Trust. As already mentioned, this organization published "[ $t]$ he statement of the use of grid and ring girls in sport," in which one can read:

We're confident that the more savvy marketers and sponsors will recognise that in the 21 st century, the presence of grid girls is unacceptable and off-putting for many men and women. By continuing the outdated practice, the likes of boxing, cycling and motor racing are potentially missing out on an opportunity to engage new audiences and excite new fans (2017)

Although this voice, indeed, opposes the presence of grid girls and hostesses in other sports disciplines, it cannot be assumed that it had a significant influence on the F1 owner's decision. Therefore, feminism should be considered here, as one can suppose, as a symptom of a wider socio-cultural transformation that has changed women's status, raised awareness of women's rights, and, as a consequence, imposed some decisions on the sports field.

The grid girls accused feminists of causing the loss of their jobs. For instance, Lauren-Jade Pope, British hostess, wrote in her tweet:

Because of these feminists, they've have cost us our jobs! I have been a grid girl for 8 years and I have never felt uncomfortable! I love my job, if I didn't I wouldn't do it! No one forces us to do this! This is our choice! (Kuczera 2018b)

The same grid girl, in one of the interviews, said:

What's annoying me more than anything is the so called feminists, they are not even really feminists, are defending us without 
even asking us how we feel, and we've lost out jobs because of this (Kuczera 2018b)

Pope was not alone in accusing the feminists. Another grid girl, Lucy Stokes, wrote:

I love my job. I'm respected, paid well \& proud to represent the team I'm working for. It's not right for anyone, let alone 'feminists' to judge our job when quite frankly they are putting so many women out of work. Where is the equality \& empowerment here? ("Formuła 1. Grid kids zastąpią grid girls. Środowisko protestuje", 2018)

The third tweet railing against feminists, which was often published, was written by Rebecca Cooper:

So the inevitable has happened, F1 grid girls have been banned. Ridiculous that women who say they are "fighting for women's rights" are saying what others should and shouldn't do, stopping us from doing a job we love and are proud to do (Prochota, 2018)

Therefore, grid girls perceive the decision to ban their presence during the races as influenced by the feminist movement. As one can suppose, according to them, from the feminists' point of view, this role is imposed by men and aims to attract male fans and sponsors. The grid girls do not agree with this perception of their work and emphasize a voluntary choice of their job. Moreover, they stress that their opinions are not taken into account when the decision was made and they also feel ignored by feminists. Additionally, they emphasized a lack of behavior that could be perceived as inappropriate, read in the frame of sexism or even harassment, which could be visible in Pope's statement and was also stressed by other grid girls, including Marta Bernarta, former grid girl and Miss Barcelona ${ }^{3}$.

The grid girls' protest was supported by other persons, mainly by drivers, including Sebastian Vettel, Nico Hulkenberg, and Max Verstappen. The last of them stated that " $[\mathrm{g}]$ rid girls had to stay", while, in Hulkenberg's opinion: "[i]t would be a great loss if we lost these beautiful jewels for eyes from the F1 paddock" ("Grid girls znikną ...", 2018). In Niki Lauda's (former driver and, now, the non-executive chairman of the Mercedes AMG Petronas F1 Team) opinion, grid girls should stay in F1; however, he was the only one who stressed that the decision was taken by men:

Men have made the decision over the heads of women. This is not doing any favours to F1 and especially not for women (Gutowski 2018)

${ }^{3}$ However, as mentioned above, the readers had an opportunity to get familiar with only a limited number of opinions; therefore, it is not possible to say if some grid girls have experienced these types of behavior. 
He emphasized, also, that women's successes in other fields of social life, as well as in other roles in F1, do not have to conflict with their jobs as grid girls:

Grid girls have always belonged in F1, and they should continue to belong in F1. Women are stepping up (into senior team roles), and they are doing it very well -- it is moving in the right direction. But one does not exclude the other. I don't want to hold back women, I want to encourage them (Gutowski 2018)

While the previous drivers' opinions emphasized rather the decorative role of the grid girls, Lauda's opinion, being focused on women and their free choice, seems to be closer to the point of view of the grid girls.

\section{Grid girls' comeback}

In 2018, the F1 season started in March in Melbourne. In April, the fans of F1 could read that, contrary to the decision taken in January, grid girls will be present during the F1 races in Monaco (in May 2018) and in Sochi (in September 2018). This decision on Monaco GP has been confirmed by Michel Boeri, the president of the Automobile Club de Monaco, who said that the girls will be present in Monaco; however, they will not be holding any name-boards. On the margins, it should be noted that Formula $\mathrm{E}$ has also decided to incorporate grid girls for some races in the current season.

Boeri, commenting on Liberty Media's decision, said, among others:

They [grid girls] look pretty and are part of the Formula 1 landscape (...) Why in the world should I stop 30 girls from earning a living? („Grid girls mają wrócić...”, 2018)

Dmitry Kozak, Russian Grand Prix organizing committee head, when asking for permission to introduce grid girls during GP in Sochi, used two main arguments. The first was related to women's attractiveness:

Girls advertise automobiles in all motorsports - it looks attractive and fitting. If we manage to reach an agreement, then we will revive the tradition. And besides, our girls are the most beautiful („Grid girls mają wrócić...”, 2018)

The second with children's safety:

Naturally it is not right to bring out children, who are afraid of the engineering, at the races. We need to be grown up here („Grid girls mają wrócić...", 2018) 
This argument is contrary to the idea of the F1's owner giving children and young drivers the opportunity to be close to their sports idols and has been used only by this one person. Moreover, the fight to bring back the grid girls has been related more to their promotional role during the races than to other reasons. As one can read, after long talks, Boeri has convinced Liberty Media that:

[b] eautiful girls at the start are the trademark of this race, attract crowds of fans and also warm up the atmosphere ("Formuła 1: "grid girls" wrócą ...", 2018)

The emphasis on a promotional role can be confirmed by the dissatisfaction of some of the promoters of GP races, for whom the replacement of women by children is a very bad decision. As noted in one article:

The Grand Prix racing promoters are also not happy with this change, because some of them own the airlines and to highlight it they wear grid girls in stewardess outfits. Obviously, this will not be possible this year (Mitak 2018)

From their point of view, the decision to bring back the hostesses during F1 GP is beneficial. Therefore, as one can suppose, the return of the grid girls for some races is related mainly to the commercial aspect of this sport and does not refer, at least in the analyzed discourse, to their right to earn money in their own chosen way.

\section{Concluding thoughts}

What happens in sport, including professional sport, cannot be considered without taking into account a wider socio-cultural context. The decision to scrap the grid girls was taken in the cultural climate of the \#metoo movement, sexual harassment scandals in Hollywood, and the time of political correctness. This entire context influences perceptions of women, male behavior towards women, and makes people aware of possible abuses. From this perspective, it is not surprising that Liberty Media, the owner of F1, has decided to stop using grid girls during F1 events because of concerns that their presence can be perceived as a form of sexism and women's objectification and, as such, is inconsistent with modern (gender) values.

Taking into account the fact that motorsports are dominated by men who constitute the vast majority of drivers, managers, and fans, grid girls, indeed, can be seen as a decorative element, persons who only accessorize the events. In this view, their sexy looks, scanty clothes, and means of presentation in the media reproduces female bodies as 'bodies for others', displayed to incite male desire. From this perspective, one cannot be surprised that the decision of Liberty Media has been described as being very sad or bad for (male) fans. Moreover, it 
seems that the drivers, at least partially, have shared this opinion.

On the other hand, one could observe the grid girls' protest, visible mainly in social media. Although, with one exception, the feminist movement was not active in the debate surrounding hostesses in sport, the grid girls have accused feminists of the loss of their jobs. This confirms that the decision to drop them was taken because of the sociocultural changes that have influenced the perception of women's roles and their representations. As a consequence, and according to the second wave of feminism, sexualized images of women are perceived as imposed by men and maintain male domination by women's objectification (Davis 2010; McLeod 2010; Khomutova and Channon 2015).

However, the grid girls' point of view seems to be closer to the third wave of feminism, which emphasizes, among other points, a different way of perception of the sexualized body which can also be seen as a tool of female agency (Gill 2003, 2008; Heywood 2008). In this view, a woman consciously uses her body, stresses its attractiveness, and presents it in a sexualized way. These arguments have been raised by the grid girls, who emphasized that their work during the F1 races was their own choice, and that they are satisfied with this job and can earn money from it. Looking on Twitter accounts, it is also possible to see that the grid girls are not only presented in a sexualized way during the GP events but maintain this way of presenting themselves in everyday life. A lot of them also work as models and hostesses during other events; therefore, physical attractiveness is their main capital in the labor market.

In this context, it cannot be forgotten that contemporary sport is a complex of sport, media, and commerce (Jhally 1984; Rowe 2004, 2013). From this perspective, the use of the female sexualized body can be perceived in two ways. First, as a means to attract sports consumers, mainly men, to make sports events more attractive, sell more tickets, and promote certain brands. On the other hand, as studies with female athletes have revealed (Lippe 2013; Jakubowska 2014), a sexualized body can be used by women themselves to increase popularity, attract sponsors, but also present the attractiveness of one's body. Of course, one can say that, even in the second case, women adapt themselves to the rules created and maintained by men, which is also illustrated by the grid girls. Both the decision to drop them and to bring them back was taken without their participation. However, a conscious use of one's own body, and emphasis on its sexuality, should not be perceived as anti-feminist; on the contrary, it can be seen within the frame of the third wave of feminism where different ways of women's representation are accepted.

The decision of F1's owner has been presented as appropriate for modern times and compatible with modern values. It has revealed a meaning of socio-cultural changes, increased awareness of gender equality and respect towards women and their bodies. The grid girls' reaction has also emphasized the role of the feminist movement and its influence on different areas of social life, including on the sports field. On the other hand, in the analyzed discourse, the decision to bring the grid girls back for some races was presented as a "re- 
turn to good custom" and "return to normality"; it was also seen as favorable for sponsors. The status of the female body in commercialized (male) sports is ambiguous. A woman's sexualized body can be perceived as both a tool of objectification and of agency. The hostesses' decorative role seems to favor the first perception; however, as mentioned at the beginning of this paper, a voice is not usually given to grid girls, ring girls, or podium girls. Further studies are needed to answer the questions of the body, its sexualization, and empowerment.

\section{REFERENCES}

Adams, Natalie and Pamela Bettis. 2003. "Commanding the Room in Short Skirts. Cheering as the Embodiment of Ideal Girlhood." Gender \& Society 17(1): 73-91. DOI: 10.1177/0891243202238979

Anderson, Eric. 2011. "Masculinities and Sexualities in Sport and Physical Cultures: Three Decades of Evolving Research." Journal of Homosexuality 5: 565-578. DOI: 10.1080/00918369.2011.563652

Balkmar, Dag. 2012. On Men and Cars. An ethnographic study of gendered, risky and dangerous relations. University dissertation from Linköping: Linköping University Electronic Press.

Bettis, Pamela and Natalie Adams. 2006. "Short Skirts and Breast Juts: Cheerleading, Eroticism and Schools." Sex Education 6(2): 121-133. DOI: 10.1080/14681810600578800

Bissell, Kimberly L. and Andrea M. Duke. 2007. "Bump, set, spike: An analysis of commentary and camera angles of women's beach volleyball during the 2004 Summer Olympics." Journal of Promotion Management 13: 35-53. DOI: 10.1300/J057v13n01_04

Bourdieu, Pierre. 2004. Męska dominacja [Masculine domination - Polish edition]. Warszawa: Oficyna Naukowa Boyatzis, Richard E. 1998. Transforming qualitative information: Thematic analysis and code development. Thousand Oaks, CA: Sage.

Braun, Virginia and Victoria Clarke. 2006. "Using thematic analysis in psychology." Qualitative Research in Psychology 3 (2): 77-101. DOI: 10.1191/1478088706qp063oa

Brennan, Siofra. 2018. "From a '60s Japanese pop star to Katie Price and Love Island's Olivia Atwood: How the grid girl ban spells the end of a long and VERY colourful part of Formula One history." Retrieved April 20, 2018 (http://www.dailymail.co.uk/femail/article-5336079/Grid-girl-ban-spellsend-colourful-Formula-One.html).

Burstyn, Varda. 2004. The Rites of Men: Manhood, Politics, and the Culture of Sport. Toronto: University of Toronto Press.

Claringbould, Inge and Annelies Knoppers. 2012. "Paradoxical practices of gender in sport-related organizations." Journal of Sport Management 26(5): 404-416. DOI: 10.1123/jsm.26.5.404

Connell, Raewyn W. 1987. Gender and Power. Cambridge: Polity Press.

Connell Raewyn W. and James W. Messerschmidt. 2005. "Hegemonic Masculinity: Rethinking the Concept." Gender \& Society 19(6): 829 - 859. DOI: 10.1177/0891243205278639

Davis, Paul. 2010. "Sexualization and sexuality in sport." Pp. 57-63. In Philosophical perspectives on gender in sport and physical activity, edited by P. Davis and C. Weaving. London: Routledge.

Fine, Michelle. 2002. Disruptive Voices: The Possibilities for Feminist Research. Ann Arbour: University of Michigan Press.

Fink, Janet. 2015. "Female athletes, women's sport, and the sport media commercial complex: Have we really "come a long way, baby"?", Sport Management Review 18(3): 331-342. DOI: 10.1016/j. smr.2014.05.001 
"Formuła 1: "grid girls" wrócą na tor w Monte Carlo. "Monako to nie jest Spa czy Monza"." 2018. Retrieved April 20, 2018 (https://www.polskieradio.pl/43/279/Artykul/2090304,Formula-1-grid-girlswroca-na-tor-w-Monte-Carlo-Monako-to-nie-jest-Spa-czy-Monza).

"Formuła 1. "Grid kids" zastąpią "grid girls"”. 2018. Retrieved April 20, 2018. (http://www.sport.pl/ F1/7,96296,22987584,formula-1-grid-kids-zastapia-grid-girls.html)

“Formuła 1. Grid kids zastąpią grid girls. Środowisko protestuje." 2018. Retrieved April 20, 2018 (http:// www.sport.pl/F1/56,96296,22988041,formula-1-grid-kids-zastapia-grid-girls.html).

"Formuła 1 już bez grid girls. Piękne kobiety nie pojawią się podczas wyścigów." 2018. Retrieved April 20, 2018 (https://sport.onet.pl/formula-1/formula-1-juz-bez-grid-girls/p5nhz2j)

„Formuła 1 obiecuje dalej mieć ładne dziewczyny na wyścigach.” 2018. Retrieved April 20, 2018 (http:// www.f1.v10.pl/Formula, 1,obiecuje,dalej,miec,ladne,dziewczyny,na,wyscigach,150709.html).

Gill, Rosalind. 2003. "From sexual objectification to sexual subjectification: the resexualisation of women's bodies in the media." Feminist Media Studies 3(1): 99-106. DOI: 10.1080/1468077032000080158

Gill, Rosalind. 2008. "Empowerment/sexism: Figuring female sexual agency in contemporary advertising." Feminism and Psychology 18(1): 35-60. DOI: 10.1177/0959353507084950

"Grid girls mają wrócić do F1 w Monako i być może w Rosji." 2018. Retrieved April 20, 2018 (http:// www.f1.v10.pl/Grid,girls,maja,wrocic,do,F1,w,Monako,i,byc,moze,w,Rosji,151731.html).

„Grid girls znikną z torów Formuły 1.” 2018. Retrieved April 20, 2018 (http://wrc.net.pl/grid-girls-znikna-z-torow-formuly-1)

Gutowski, Cezary. 2018. „Lauda o właścicielach Formuły 1: Czy oni oszaleli?”. Retrieved April 20, 2018 (https://www.przegladsportowy.pl/motosporty/formula-1/wlasciciele-formuly-1-nie-chca-grid-girlsw-f1/72r0hwk).

Heywood, Leslie. 2008. "Third-wave feminism, the global economy, and women's surfing: Sport as stealth feminism in girls' surf culture." Pp. 63-82. In Next wave cultures: Feminism, subcultures, activism, edited by A. Harris. Oxon: Routledge.

Heywood, Leslie and Shari L. Dworkin. 2003. Built to win: The female athlete as cultural icon. London: University of Minnesota Press.

Hovden, Jorid. 2000. "Heavyweight" men and younger women? The gendering of selection processes in Norwegian sport organizations." NORA - Nordic Journal of Feminist and Gender Research 8(1): 17-32. DOI: $10.1080 / 080387400408035$

Jakubowska, Honorata. 2014. Gra ciatem. Praktyki i dyskursy różnicowania ptci w sporcie. Warszawa: Wydawnictwo Naukowe PWN.

Jhally, Sut. 1984. "The Spectacle of Accumulation: Material and Cultural Factors in the Evolution of the Sport/ Media Complex." The Insurgent Sociologist 12(3): 41-57. DOI: 10.1177/089692058401200304

Khomutova, Anastasiya and Alex Channon. 2015. "Legends' in 'Lingerie': Sexuality and Athleticism in the 2013 Legends Football League US Season." Sociology of Sport Journal 32(2): 161-182. DOI: 10.1123/ssj.2014-0054

Kim, Eunyi, Walkosz, Barbara J. and Joel Iverson. 2006. "USA Today's coverage of the top women golfers, 1998-2001." The Howard Journal of Communications 17: 307-321. DOI: $10.1080 / 10646170600966550$

Krueger, Richard A. and Mary A. Casey. 2000. Focus Groups. A Practical Guide for Applied Research (3rd Edition). Thousand Oaks, CA: Sage Publications.

Kuczera, Łukasz. 2018a. "Formuła E popiera decyzję ws. grid girls. Witamy w XXI wieku." Retrieved April 20, 2018 (https://sportowefakty.wp.pl/formula-1/735504/formula-e-popiera-decyzje-ws-grid- 
girls-witamy-w-xxi-wieku).

Kuczera, Łukasz. 2018b. “Grid girl uderzają w feministki. Nie pytają nas o zdanie.” Retrieved April 20, 2018 (https://sportowefakty.wp.pl/formula-1/735612/grid-girls-uderzaja-w-feministki-nie-pytaja-nas-o-zdanie).

Letherby, Gayle and Gillian Reynolds, eds., 2009. Gendered Journeys, Mobile Emotions. Aldershot: Ashgate.

Lippe, Gerd von der. 2013. "Discourses on women's dress codes in beach volleyball and boxing: In the context of the current consumer culture." Pp. 140-158. In Gender and Sport: Changes and Challenges, edited by G. Pfister and M. K. Sisjord. Münster: Waxmann.

McCormack, Mark. 2011. "Hierarchy Without Hegemony: Locating Boys in an Inclusive School Setting." Sociological Perspectives 1: 83-101. DOI: 10.1525/sop.2011.54.1.83

McKay, Jim, Michael A. Messner and Donald F. Sabo, eds., 2000. Masculinities, Gender Relations and Sport. London: Sage.

McLeod, Carolyn. 2010. "Mere and partial means: The full range of the objectification of women." Pp. 64-82. In Philosophical perspectives on gender in sport and physical activity, edited by P. Davis and C. Weaving. London: Routledge.

Mellström, Ulf. 2002. "Patriarchal Machines and Masculine Embodiement." Science, Technology and Human Values 27(4): 460-478. DOI: 10.1177/016224302236177

Mellström, Ulf. 2004. "Machines and Masculine Subjectivity. Technology as an Integral Part of Men's Life Experiences." Men and Masculinities. Special Issue: Masculinities and Technologies, 6(4): 368-382. DOI: $10.1177 / 1097184 X 03260960$

Messner, Michael A., 1992. Power at Play: Sports and the Problem of Masculinity. Boston: Beacon Press.

Mitak, Przemysław. 2018. "Promotorzy GP w Rosji także naciskają na powrót grid girls.” Retrieved April 20, 2018 (http://www.motorsportgp.pl/aktualnosci-formula-1/promotorzy-gp-rosji-takze-naciskajana-powrot-grid-girls).

Moritz, Amy. 2011. "Cheerleading: not just for the sidelines anymore." Sport in Society 14(5): 660-669. DOI: $10.1080 / 17430437.2011 .575109$

Organista, Natalia and Zuzanna Mazur. 2016. „„Piękne kobiety pięknie tańczą” czy „uprzedmiotowienie i upokorzenie"? Analiza dyskursu o cheerleadingu w kontekście mistrzostw Europy w piłce ręcznej mężczyzn w 2016 roku." Przegląd Socjologii Jakościowej 12(4): 118-143.

Pfister, Gertrud and Sabine Radtke. 2009. "Sport, women and leadership: Results of a project on executives in German sports organizations.” European Journal of Sport Science 9: 229-243. DOI: $10.1080 / 17461390902818286$

Prochota, Andrzej. 2018. „Grid girls niezadowolone z decyzji F1. Kochamy naszą pracę.” Retrieved April 20, 2018 (https://sportowefakty.wp.pl/formula-1/735585/grid-girls-niezadowolone-z-decyzji-f1-kochamy-nasza-prace).

Pronger, Brian. 1990. The Arena of Masculinity: Sports, Homosexuality and the Meaning of Sex. New York: St. Martin's Press.

Rowe, David. 2004. Sport, Culture and the Media. Berkshire: Open University Press.

Rowe, Rowe. 2013. “The Sport/Media Complex.” Pp. 61-77. In A Companion to Sport, edited by D.L. Andrews and B. Carrington. Chichester: Blackwell Publishing Ltd

Saner, Emine. 2018. “'Grid girls': F1 follows darts by calling time on women in hotpants." Retrieved April 20, 2018 (https://www.theguardian.com/world/2018/feb/02/grid-girls-f1-follows-darts-by-callingtime-on-women-in-hotpants).

Smart, Barry. 2005. The Sport Star: Modern Sport and the Cultural Economy of Sporting Celebrity. London: Sage Publications. 
Uteng, Tanu Priya and Tim, Cresswell, eds. 2008. Gendered Mobilities. Aldershot: Ashgate.

"Which sports still use 'walk-on girls'?". 2018. Retrieved April 20, 2018 (http://www.bbc.com/news/uk42907570). 